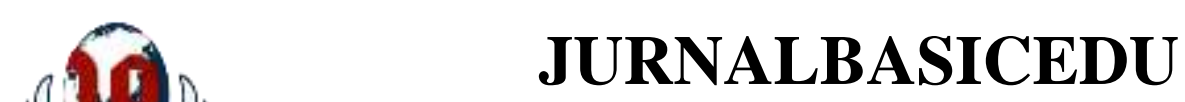

Volume 6 Nomor 1 Tahun 2022 Halaman 581 - 590

Research \& Learningin Elementary Education https://jbasic.org/index.php/basicedu

\title{
Pengembangan Media Cerita Bergambar Tentang Penjajahan Belanda untuk Meningkatkan Minat Baca Siswa Sekolah Dasar
}

\author{
Diah Tara Dewi \\ Universitas Islam Negeri Sunan Kalijaga Yogyakarta, Indonesia \\ E-mail: 24diahtara@gmail.com
}

\begin{abstract}
Abstrak
Tujuan dari penelitian ini ialah untuk mengembangkan media pembelajaran cerita bergambar untuk meningkatkan minat baca siswa kelas V Sekolah Dasar pada mata pelajaran IPS. Penelitian ini menggunakan jenis penelitian Research and Developnment (R\&D). Dari hasil studi pendahuluan, dalam proses pembelajaran guru hanya menggunakan media cetak biasa yaitu bahan ajar kelas $\mathrm{V}$ sehingga siswa kurang bersemanagat dalam kegiatan belajar dan hal inilah yang menjadikan rendahnya minat baca pada diri siswa. Berdasarkan hasil studi pendahuluan maka penulis mengembangkan produk buku cerita bergambar "Kejamnya Penjajahan Belanda" untuk meningkatkan minat baca pada diri siswa kelas V SD. Draf produk diuji oleh dua ahli materi dan satu ahli media. Hasil validasi ahli materi pertama dengan skor 82,5\% dalam kategori sangat tinggi dan hasil validasi dari ahli materi dua diperoleh skor 78,75\% dengan jkategori tinggi. Hasil validasi oleh pakar media diperoleh skor $75 \%$ dalam kategori tinggi.
\end{abstract}

Kata Kunci: media pembelajaran, cerita bergambar, minat baca

\begin{abstract}
The purpose of this study is to develop the illustrated history media to increase the interest of reading elementary school $V$-students in social studies. It employs the type of research and developmentally research $(r \& d)$. From the introductory study results, in the learning process the teacher USES only the normal printing media the class $v$ material so that students lack semantics in study activities and this makes reading less an interest in students. Based on preliminary studies, the author developed a storybook product depicting "the contempt of Dutch colonization" to increase the interest of reading in v-grade students. The product drafts were tested by two masters of matter and one media expert. The results of the first material expert validation with a score of $82.5 \%$ in the extremely high category and the validation results from the material expert two obtained a score of $78.75 \%$ at the high category. Validation by a media expert obtained a $75 \%$ score in high categories.
\end{abstract}

Keywords: learning media, picture stories, interest in reading

Copyright (c) 2022 Diah Tara Dewi

$\triangle$ Corresponding author :

Email : 24diahtara@gmail.com

DOI $\quad:$ https://doi.org/10.31004/basicedu.v6i1.1966

ISSN 2580-3735 (Media Cetak)

ISSN 2580-1147 (Media Online) 


\section{PENDAHULUAN}

Media merupakan suatu alat hubung yang berfungsi sebagai perantara dalam penyampaian berita, kabar, ataupun informasi. National Education Association yang dikutip oleh Apriliani dan Radia menjelaskan bahwa media adalah suatu objek atau barang yang digunakan dalam suatu kegiatan yang dapat dilihat, didengar, dibaca, dan dirasakan. Media berperan sebagai alat bantu guru dalam kegiatan pembelajaran serta dapat dijadikan sebagai magnet yang dapat memikat siswa agar memiliki dorongan dalam mengikuti kegiatan belajar mengajar (Apriliani \& Radia, 2020). Canggungnya kegiatan pembelajaran serta perasaan bosan dan malas yang terjadi pada siswa dalam proses belajar mengajar salah satu penyebabnya adalah karena pembelajaran berpusat pada guru dan sifat monoton guru dalam mengajar, guru hanya menjelaskan materi dengan membaca dan siswa mendengarkannya. Kegiatan pembelajaran seperti ini harus disertai dengan penggunaan media pembelajaran agar terciptanya suatu pembelajaran yang berkualitas (Nurseto, 2012). Dalam proses pembelajaran guru mempunyai tugas serta tanggung jawab untuk menentukan media pembelajaran serta bahan ajar yang tepat guna terwujudnya pembelajaran sesuai dengan tujuan dari kurikulum 2013 (Kholifah \& Kristin, 2021).

Kurikulum 2013 bertujuan untuk mempersiapkan rakyat Indonesia agar memiliki kecakapan dalam kehidupan dengan berkepribadian yang beriman, bermanfaat, berinovasi, imajinatif, berakhlak mulia serta ikut serta dalam membangun kehidupan yang lebih baik dalam lingkup masyarakat, bangsa, negara, dan peradaban dunia (Kurniawati \& Koeswanti, 2020). Dalam Kurikulum 2013 pembelajaran yang diterapkan adalah pembelajaran tematik, pembelajarn tematik merupakan kumpulan dari beberapa tema yang memuat pokok bahasan pengajaran yang kemudian diintegrasikan ke dalam satu topik (Apriliani \& Radia, 2020). Pembelajaran tematik menurut Rusman yang dikutip oleh (Kholifah \& Kristin, 2021) merupakan gabungan dari beberapa mata pelajaran yang saling berkaitan yang disusun untuk memperkaya pengalaman siswa. Pembelajaran tematik ini diterapkan pada siswa tingkat sekolah dasar (Sari \& Syamsi, 2015). Mata pelajaran yang diintegrasikan dalam pembelajaran tematik yaitu mata pelajaran Bahasa Indonesia, Pendidikan Pancasila dan Kewarganegaraan, Ilmu Pengetahuan Alam, Ilmu Pengetahuan Sosial, Matematika, Pendidikan Jasmani Olahraga dan Kesehatan, dan Seni Budaya dan Prakarya (Julianti \& Mawardi, 2018).

Ilmu Pengetahuan Sosial (IPS) merupakan salah satu mata pelajaran yang terdapat di tingkat sekolah dasar. Pembelajaran IPS di jenjang sekolah dasar mempunyai tujuan untuk menumbuhkan masyarakat dan negara. IPS bukanlah sekedar ilmu social yang disederhanakan, namun mempunyai nilai untuk mempersiapkan siswa dalam menyiapkan tantangan kehidupan mendatang yang akan dihadapi (Lestari, 2016). Salah satu materi yang terkandung dalam muatan pelajaran IPS kelas V SD adalah materi mengenai penjajahan bangsa Belanda, Penjajahan Bangsa Jepang, hingga peristiwa kemerdekaan Indonesia. Materimateri tersebut merupakan peristiwa penting bagi Indonesia dan seluruh rakyat Indonesia diharapkan mengetahui peristiwa tersebut. Namun karena banyaknya kejadian- kejadian yang termuat dalam materi tersebut serta kurangnya kreatifitas pembelajaran yang diciptakan oleh guru menjadikan siswa bosan dan kurangnya minat siswa dalam pembelajaran. Dalam mengatasi hal tersebut dapat diterapkan media berupa cerita bergambar.

Cerita bergambar merupakan sebuah cerita yang didalamnya disusun dengan gambar- gambar (Apriliani \& Radia, 2020) dan dengan tata Bahasa yang ringan yang mudah dipahami oleh pembaca (Putrisilia \& Airlanda, 2021). Dengan penerapan media cerita bergambar yang dilakukan oleh guru dapat mewujudkan daya tarik siswa dan mengatasi kebosanan siswa dalam menerima materi pelajaran. Konten cerita bergambar yang menarik dan alur cerita yang mudah dicerna dapat menumbuhkan ketertarikan siswa untuk membaca (Vindaswari \& Ulfah, 2018). Dengan bantuan buku cerita bergambar diharapkan siswa dapat menerima informasi berdasarkan isi dari cerita yang disampaikan. Yang pada akhirnya buku cerita bergambar dikategorikan sebagai media yang layak diterapkan dalam kegiatan pembelajaran di tingkat sekolah dasar 
(Nurjanah \& Hakim, 2018). Buku cerita bergambar memiliki peran sebagai alat bantu atau media siswa dalam membaca dan memperkaya kosakata pada diri siswa (Tarigan, 2018).

Piaget dalam Tarigan mengatakan bahwa anak usia 11 tahun sedang tumbuh dan berkembang dalam mengeksplore kosakata hingga 40.000 kata serta meningkatnya imajinasi, nalar, dan keterampilan analisa (Piaget \& Inhelder, 2010) (Tarigan, 2018). Membaca merupakan suatu langkah dalam mengkaji sesuatu dan dapat mendalami ilmu yang dipelajari dan mengambil amanat yang terkandung dalam suatu bacaan sehingga dapat dijabarkan dalam bentuk tulisan (Dafit, 2017). Membaca menjadi kebutuhan utama siswa dalam rangka memperkaya kosakata dan memperdalam tata Bahasa selama kegiatan pembelajaran di jenjang sekolah dasar (Kholifah \& Kristin, 2021). Penanaman budaya membaca sejak dini menjadi suatu tumpuan pendidikan dasar agar proses pembelajaran menjadi lebih sempurna. Pembiasaan membaca merupakan suatu kunci berhasilnya seseorang dalam menuntut ilmu (Rosyana, Ilhamdi, \& Dewi, 2021). Kebiasaan membaca harus diwujudkan dengan meningkatnya minat baca. Kualitas sumber daya manusia otomatis dengan adanya peningkatan minat baca pada diri siswa (Kasiyun, 2015). Dengan meningkatnya minat baca maka akan menjadikan siswa menjadi lebih mudah dalam memahami suatu bacaan.

Minat baca menjadi investasi utama untuk peserta didik. Peserta didik akan bermanfaat dari minat yang telah terbentuk dalam kegiatan pembelajaran. Tingginya minat baca seseorang dapat dilihat dari cara orang tersebut memanfaatkan waktunya untuk membaca dengan dorongan dari dirinya sendiri dan tanpa paksaan dari pihak manapun (Tarigan, 2018). Sehingga rendahnya minat baca muncul dari dalam diri seseorang pula, meskipun buku bacaan sudah tersedia namun apabila tidak memiliki dorongan dan keinginan dalam diri tentu minat baca akan semakin rendah. Menurut Budiningsih dalam (Lubis, 2018) yang dikutip oleh (Kholifah \& Kristin, 2021) mengatakan bahwa minat baca siswa di Indonesia tergolong rendah, tertinggal jauh dibandingkan negara Singapura dan Malaysia. Masyarakat Indonesia merasa bahwa informasi bias diakses deang mudah melalui media social daripada buku. Perkembangan buku tertinggal jauh dengan upgrade media sosial.

Rendahnya minat baca dapat disebabkan oleh beberapa factor, salah satunya adalah kurangnya kreatifitas guru dalam penerapan media pembelajaran, penggunaan bahan ajar yang sesuai dengan tingkat perkembangan siswa, ataupun cara mengajar guru yang monoton sehingga menjadikan siswa jenuh dan bosan dalam proses pembelajaran. Dalam rangka memecahkan permasalahan kurangnya minat baca siswa, maka seorang pendidik harus mampu menciptakan sebuah inovasi dalam pembelajaran sehingga tampaklah suatu pembelajaran yang menyenangkan, aktif, serta efektif (Lindasari \& Wahyudi, 2021). Salah satu upaya yang dapat dilakukan untuk mengatasi rendahnya mint abaca pada siswa adalah dengan menggembangkan produk media pembelajaran berbentuk cerita bergambar. Berdasarkan hasil wawancara dengan guru kelas V MI Mambaul Ulum Jepara diperoleh informasi bahwa siswa kelas $\mathrm{V}$ belum maksimal dalam kegiatan pembelajaran, terutama pada mata pelajaran yang terdapat banyak bacaan. Salah satunya adalah mata pelajaran IPS, rendahnya minat baca siswa menjadikan proses pembelajaran berjalan kurang efektif dan efisien.

Tujuan dari penelitian ini adalah untuk menghasilkan bahan ajar IPS berbentuk cerita bergambar pada materi "penjajahan Belanda". Pengembangan bahan ajar dirancang semenarik mungkin dan dengan gaya Bahasa yang sederhana sehingga mudah difahami dan sesuai dengan pemahaman tata Bahasa serta kosa kata pada siswa usia sekolah dasar. Bahan ajar cerita bergambar ini dapat digunakan guru sebagai jembatan dalam penyampaian materi IPS yang mana diharapkan siswa tertarik dan mampu meningkatkan minat baca siswa. Oleh karena itu dalam rangka memecahkan permasalahan di atas, maka akan dikembangkan suatu produk atau media berupa bahan ajar berbentuk cerita bergambar dengan judul penelitian "Pengembangan Media Cerita Bergambar Tentang Penjajahan Belanda Untuk Meningkatkan Minat Baca Siswa Kelas V Sekolah Dasar" 


\section{METODE PENELITIAN}

Penelitian ini menggunakan jenis penelitian Research and Development (R\&D). Research and Development ialah metode yang digunakan dalam sebuah penelitian untuk menghasilkan suatu produk serta dilakukan uji efektifitas dari suatu produk (Sugiyono, 2015). Menurut (Sukmadinata, 2016) R\&D merupakan proses pengembangan suatu produk yang baru, maupun produk yang sebelumnya pernah digunakan dan produk yang dikembangkan tersebut dapat dipertanggung jawabkan. Dalam penelitian ini produk yang akan dihasilkan adalah buku cerita bergambar untuk meningkatkan minat baca siswa kelas $\mathrm{V}$ sekolah dasar pada mata pelajaran IPS materi tentang penjajahanbangsa Belanda.

Penelitian pengembangan ini menggunakan teori Borg and Gall yang dimodifikasi menjadi tiga tahapan yaitu 1) Studi pendahuluan, pada tahapan ini terdiri dari 3 langkah yaitu: studi kepustakaan, survey lapangan, dan draf produk, 2) Pengembangan, pada tahapan ini terdiri dari 3 langkah, yaitu uji validitas, uji coba sampel terbatas dan uji coba sampel lebih luas, 3) uji produk menggunkan eksperimen dan sosialisasi produk. Peneliti membatasi penelitian ini hanya sampai pada tahap uji validitas ahli materi dan uji validitas ahli media.

\section{HASIL DAN PEMBAHASAN}

Studi pendahuluan dilaksanakan dengan cara pengamatan dan wawancara kepada guru kelas V MI Mambaul Ulum Mantingan Tahunan Jepara. Dalam kegiatan pembelajaran guru hanya menggunakan buku tema saja dan meminta siswa untuk membacanya. Hal ini menjadi penyebab siswa kurang semangat dalam kegiatan pembelajaran dan tentunya siswa malas dalam membaca. Kurangnya inovasi guru dalam pembelajaran, yaitu penggunaan media pembelajaran yang minim dan metode pembelajaran yang kurang tepat mengakibatkan siswa sulit dalam memahami materi yang disampaikan oleh guru.

Berdasarkan permasalahan yang dihadapi oleh siswa kelas V MI Mambaul Ulum Jepara, penulis melakukan pengembangan bahan ajar berupa buku cerita bergambar dalam rangka meningkatkan minat baca siswa. Produk yang dikembangkan adalah buku cerita bergambar dengan judul "Kejamnya Penjajahan Belanda". Buku cerita bergambar tersebut memuat materi IPS tentang penjajahan pada masa Belanda. Cerita bergambar ini terdiri dari cover, kata pengantar, isi materi, dan daftar pustaka. Cover berisi judul dan nama penulis, kata pengantar berisi tentang kata- kata yang disampaikan penulis berupa tujuan yang ingin dicapai dengan diterapkannya buku cerita bergambar tersebut yaitu untuk meningkatkan motivasi serta minat baca siswa, isi materi memuat materi IPS mengenai penjajahan Belanda dari awal mula datangnya Belanda ke Indonesia sampai dengan mundurnya Bangsa Belanda dari Bangsa Indonesia, dan daftar pustaka berisi sumber materi yang digunakan dalam menyusun cerita bergambar. Berikut adalah tampilan dari media cerita bergambar "Kejamnya Penjajahan Belanda"
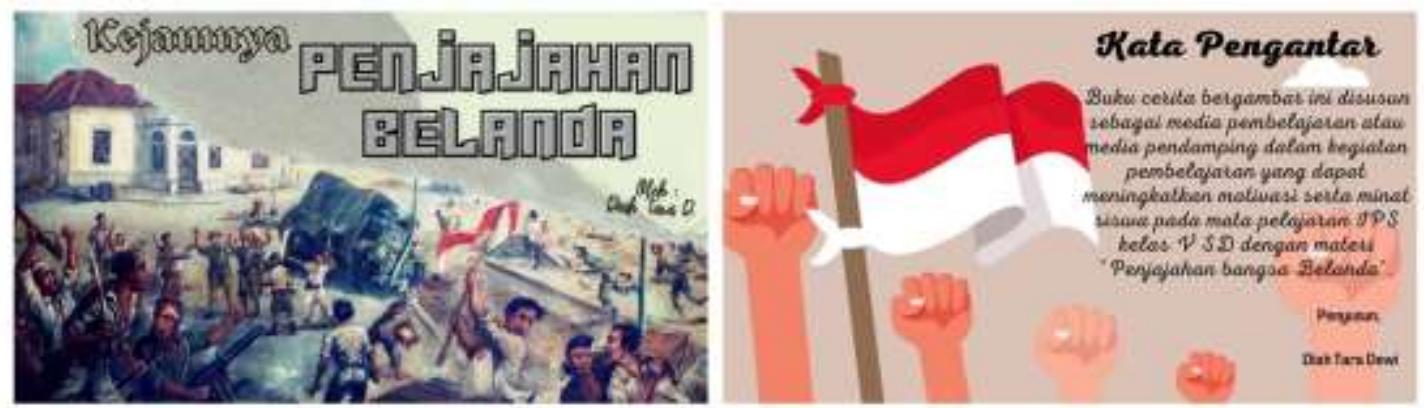

Gambar 1. Cover dan Kata Pengantar Buku Cerita Bergambar 

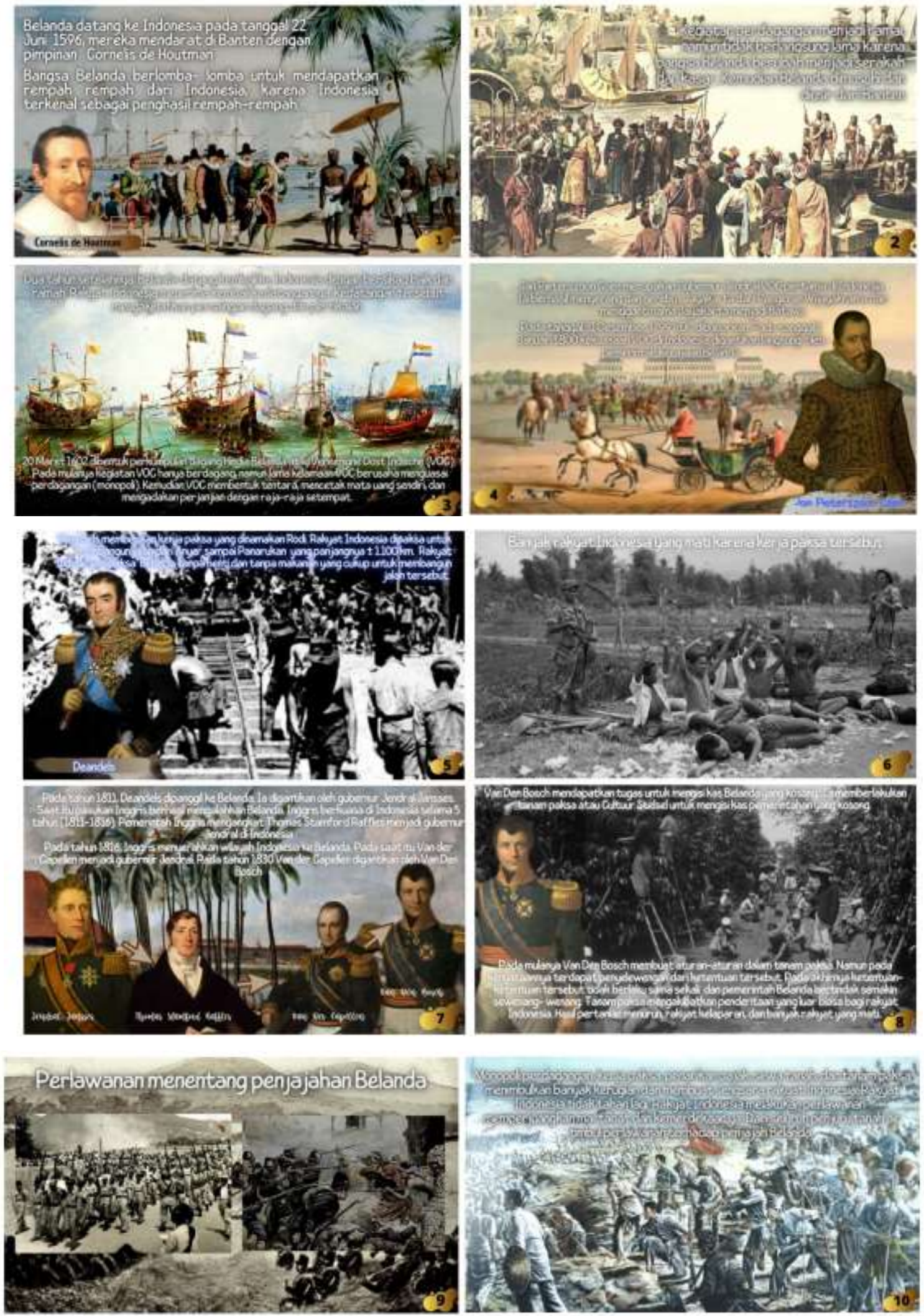


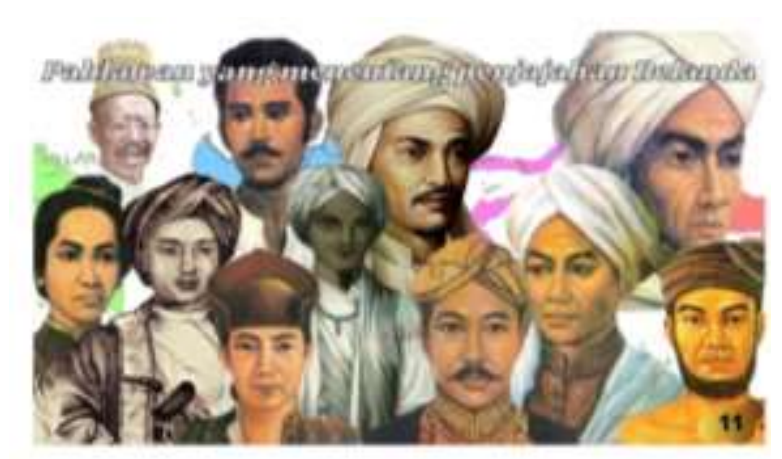

Gambar 2. Isi Cerita Bergambar

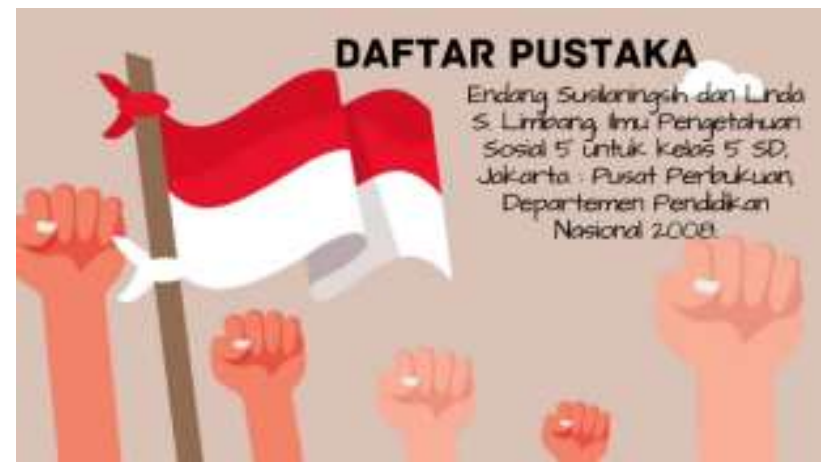

Gambar 3. Daftar Pustaka

Setelah pengembanagn draf produk, maka langkah selanjutnya adalah uji produk yang mana dilakukan uji ahli materi dang uji ahli media. Uji ahli materi pembelajaran oleh dua dosen dan uji ahli media oleh satu dosen. Terdapat 4 aspek yang divalidasi oleh dosen ahli materi, yaitu aspek relevansi, keakuratan, kelengkapan serta aspek Bahasa. Setiap aspek masing- masing mempunyai 4 indikator. Berikut aspek dan indicator yang akan divalidasi oleh ahli materi.

Tabel 1. Aspek Validasi Ahli Materi

\begin{tabular}{|c|c|c|}
\hline No & Aspek & Indikator \\
\hline \multirow{4}{*}{1} & \multirow{4}{*}{ Relevansi } & Intensitas isi cerita selaras dengan tahap tumbuh kembang siswa \\
\hline & & Integritas isi cerita selaras dengan tahap tumbuh kembang siswa \\
\hline & & Ilustrasi buku menarik minat siswa dalam mengikuti alur cerita \\
\hline & & Pemaparan isi cerita memenuhi standar kurikulum \\
\hline \multirow{4}{*}{2} & \multirow{4}{*}{ Keakuratan } & Isi cerita mengandung pelajaran nilai- nilai kehidupan \\
\hline & & Isi cerita memuat perilaku social dalam kehidupan sehari-hari \\
\hline & & Materi yang disajikan dapat diterapkan dalam kehidupan sehari- hari \\
\hline & & $\begin{array}{l}\text { Materi yang disajikan dapat dijadikan pelajaran dalam kehidupan sehari- } \\
\text { hari }\end{array}$ \\
\hline \multirow{4}{*}{3} & \multirow{4}{*}{ Kelengkapan } & Memaparkan kompetensi yang harus didapatkan siswa \\
\hline & & Manfaat media cerita bergambar bagi siswa dalam memahami materi \\
\hline & & Manfaat media cerita bergambar dalam meningkatkan minat baca siswa \\
\hline & & Cerita yang disajikan sesuai dnegan materi pada bahan ajar \\
\hline \multirow{4}{*}{4} & \multirow{4}{*}{ Bahasa } & Kecermatan menggunakan ejaan \\
\hline & & Penggunaan istilah baku \\
\hline & & Penyusunan struktur kalimat \\
\hline & & Penggunaan Bahasa sesuai tahap perkembangan siswa \\
\hline
\end{tabular}


Setiap aspek terdapat 4 indikator, skor maksimal dari tiap indicator adalah 5 poin, jadi skor ideal setiap aspek adalah 20 poin. Setelah aspek dan indicator validasi untuk ahli materi ditentukan, kemudian dilakukan uji validitas ahli materi dengan hasil sebagai berikut:

Tabel 2. Kategori Persentase

\begin{tabular}{cc}
\hline Interval & Kategori \\
\hline $100 \%-81 \%$ & Sangat Tinggi \\
\hline $80 \%-61 \%$ & Tinggi \\
\hline $60 \%-41 \%$ & Sedang \\
\hline $40 \%-21 \%$ & Cukup \\
\hline $20 \%-0 \%$ & Rendah
\end{tabular}

Berdasarkan tabel 2 dijelaskan bahwa skor hasil persentase uji validasi dikategorikan menjadi 4, yaitu sangat tinggi, tinggi, sedang, cukup, dan rendah. Kategori sangat tinggi artinya media yang telah dikembangkan layak untuk diuji cobakan, kategori tinggi layak untuk diuji cobakan, kategori sedang produk dapat digunakan dan perlu dilakukan revisi agar produk menjadi sempurna, kategori cukup artinya perlu dilakukan perbaikan dalam pengembangan produk, dan kategori rendah artinya ialah produkyang dikembangkan dinyatakan tidak layak untuk diuji cobakan kepada responden.

Tabel 3. Presentase Kelayakan dari Ahli Materi 1

\begin{tabular}{lllll}
\hline Aspek & Skor Ideal & Skor Aktual & \multicolumn{1}{c}{$\begin{array}{c}\text { Presentase } \\
\text { Kelayakan }\end{array}$} & Kategori \\
\hline 1 & 20 & 17 & $85 \%$ & Sangat Tinggi \\
\hline 2 & 20 & 14 & $70 \%$ & Tinggi \\
\hline 3 & 20 & 17 & $85 \%$ & Sangat Tinggi \\
\hline 4 & 20 & 18 & $90 \%$ & Sangat Tinggi \\
\hline
\end{tabular}

Tabel 3 adalah hasil validasi dari ahli materi 1 dengan rata- rata 82,5\% dalam kategori sangat tinggi. Pada aspek 1 yaitu aspek relevansi diperoleh hasil sebesar $85 \%$ dalam kategori sangat tinggi, aspek 2 diperoleh hasil 70\% dalam kategori tinggi, aspek 3 diperoleh hasil $85 \%$ dalam kategori sangat tinggi, dan aspek 4 sebesar 90\% dalam kategori sangat tinggi. Artinya, buku cerita bergambar yang telah dikembangkan layak untuk diterapkan dalam kegiatan pembelajaran.

Tabel 4. Presentase Kelayakan dari Ahli Materi 2

\begin{tabular}{lllll}
\hline Aspek & Skor Ideal & Skor Aktual & \multicolumn{1}{c}{$\begin{array}{c}\text { Presentase } \\
\text { Kelayakan }\end{array}$} & Kategori \\
\hline 1 & 20 & 16 & $80 \%$ & Tinggi \\
\hline 2 & 20 & 13 & $65 \%$ & Tinggi \\
\hline 3 & 20 & 16 & $80 \%$ & Tinggi \\
\hline 4 & 20 & 18 & $90 \%$ & Sangat Tinggi \\
\hline Rata- rata hasil validasi ahli materi 2 & $78,75 \%$ & Tinggi \\
\hline
\end{tabular}

Tabel 4 merupakan hasil validasi dari ahli materi 2. Dalam aspek 1 diperoleh presentase sebesar $80 \%$ dalam kategori tinggi, pada aspek 2 diperoleh hasil 65\% dalam kategori tinggi, aspek 3 diperoleh hasil 80\% dalam kategori tinggi dan aspek 4 diperoleh hasil $90 \%$. Dan hasil akhir atau rata- rata skor keseluruhan dari ahli media 2 adalah 18,75 dalam kategori tinggi. 
Selain validasi dari ahli materi, penulis juga melakukan validasi dari ahli media. Validasi ahli media terdiri dari 3 aspek, yaitu 1) Aspek koherensi sajian dengan tujuan pembelajaran yang berpusat pada siswa, 2) cara penyajian, dan 3) keterbacaan dan kekomunikatifan. Dalam setiap aspek memiliki 4 indikator, dan setiap indicator mempunyai skor masksimal 5. Indicator dari aspek koherensi sajian dengan tujuan pembelajaran adalah 1) mendorong siswa untuk mengamalkan isi cerita, 2) mengambil ibrah dari setiap kejadian, 3) mendorong terjadinya interaksi siswa dengan bahan ajar, 4) mendorong siswa untuk mempererat persatuan dan kesatuan. Indicator dari aspek cara penyajian yaitu 1) desain buku cerita mewakili isi cerita, 2) kesesuaian ilustrasi dalam memberikan contoh kehidupan nyata, 3) ilustrasi menarik, 4) ilustrasi dalam buku cerita memperjelas latar dan susunan cerita. Indicator dari aspek keterbacaan dan kekomunikatifan adalah 1) kosakata yang sesuai dengan usia anak, 2) Panjang kalimat sesuai dengan tingkap pemahaman anak, 3) Istilah baku, 4) penyusunan struktur kalimat.

Tabel 5. Presentase Kelayakan dari Ahli Media

\begin{tabular}{llllll}
\hline Aspek & Skor Ideal & Skor Aktual & \multicolumn{2}{c}{$\begin{array}{l}\text { Presentase } \\
\text { Kelayakan }\end{array}$} & Kategori \\
\hline 1 & 20 & 14 & $70 \%$ & Tinggi & \\
\hline 2 & 20 & 16 & $80 \%$ & Tinggi & \\
\hline 3 & 20 & 15 & $75 \%$ & Tinggi & \\
\hline & Rata- rata hasil validasi ahli media & $75 \%$ & Tinggi & \\
\hline
\end{tabular}

Berdasarkan tabel 5, kelayakan dari ahli media diperoleh hasil rata- rata sebesar 75\%. Yang mana pada spek 1 diperoleh hasil 70\% dalam kategori tinggi, aspek 2 diperoleh hasil 80\% dalam kategori tinggi dan aspek 3 diperoleh hasil $75 \%$ dalam kategori tinggi.

Perbaikan dari ahli materi dan ahli media yaitu disarankan untuk menambahkan beberapa kalimat yang berisi tentang hikmah yang dapat diambil dari kisah penjajahan belanda dan memberikan contoh sika papa saja yang dapat diteladani dari kisah perjuangan para pahlawan dalam melawan penjajahan. Meskipun terdapat beberapa perbaikan, namun media cerita bergambar dengan judul "Kejamnya Penjajahan Belanda" ini layak diterapkan pada pembelajaran IPS kelas V untuk meningkatkan minat baca siswa.

Hasil dari studi pendahuluan masalah yang nampak adalah terbatasnya media pembelajaran yang digunakan dalam kegiatan pembelajaran.keterbatasan media pembelajaran dan penggunaan media pembelajaran yang tidak tepat dapat menyebabkan siswa kurang semangat, minat baca menurun, dan pada akhirnya pembelajaran tidak berjalan secara efektif. Media pembelajaran yang menarik dan sesuai dengan materi dan kondisi serta perkembangan siswa tentu akan menumbuhkan dan meningkatkan minat baca siswa.

Dalam proses pengembangan media pembelajaran cerita bergambar mata pelajaran IPS kelas V SD terdapat beberapa keterbatasan dalam penelitian, antara lain 1) Pengembangan media cerita bergambar hanya dibatasi sampai pada uji validasi ahli materi dan ahli media saja, belum samapi pada tahap uji lapangan atau penerapan pada siswa sehingga belum diketahui secara pasti seberapa efektifnya media cerita bergambar jika digunakan dalam pembelajaran. 2) Hasil dari cerita bergambar masih dalam bentuk soft file, belum berbentuk print out. 3) Media cerita bergambar haya dapat diterapkan pada siswa kelas V dengan materi penjajahan bangsa Belanda saja.

\section{KESIMPULAN}

Produk yang dihasilkan adalah buku cerita bergambar. Materi yang termuat dalam media cerita bergambar ini adalah materi mata pelajaran Ilmu Pengetahuan Sosial (IPS) kelas V sekolah dasar yaitu tentang penjajahan bangsa Belanda. Hasil validasi ahli materi satu diperoleh rata- rata $82,5 \%$ pada interval $100 \%$ $81 \%$ dalam kategori sangat tinggi, dan hasil validasi oleh ahli materi dua diperoleh skor rata- rata $78,75 \%$ 
pada interval $80 \%$ - 61\% dalam kategori tinggi. Sedangkan hasil validasi oleh ahli media diperoleh skor $75 \%$ pada interval $80 \%$ - 61\% dalam kategori tinggi. Berdasarkan hasil uji validasi para ahli maka pengembanagn cerita bergambar "Kejamnya Penjajahan Belanda" layak digunakan dalam kegiatan pembelajaran guna meningkatkna minat baca siswa kelas V sekolah dasar.

\section{DAFTAR PUSTAKA}

Apriliani, S. P., \& Radia, E. H. (2020). Pengembangan Media Pembelajaran Buku Crita Bergambar Untuk Meningkatkan Minat Mmembaca Sekolah Dasar. Jurnal Basicedu, 4(4), 994-1003.

Dafit, F. (2017). Pengaruh Model Pembelajaran Multiliterasi Terhadap Kemampuan Membaca Siswa Sekolah Dasar. Jurnal Inovasi Pendidikan Dan Pembelajaran Sekolah Dasar, 1(1), 87-100.

Dessiane, S. T., \& Hardjono, N. (2020). Efektifitas Media Pembelajaran Cerita Bergambar Atau Komik Bagi Siswa Sekolah Dasar. Jurnal Pendidikan Dan Konseling, 2(1), 42-46.

Hidayah, N., \& Rohmatillah. (2021). Pengembanagn Buku Cerita Bergambar Islami Berbasis Pendidikan Lingkungan Hidup Untuk Pembelajaran Membaca Di Sd/Mi. Ar-Riayah : Jurnal Pendidikan Dasar, 5(1), 27-38.

Julianti, I. A., \& Mawardi. (2018). Penerapan Desain Pembelajaran Tematik Integratif Alternatif Berbasis Sub-Tema Untuk Meningkatkan Kebermaknaan Dan Hasil Belajar. Publikasi Pendidikan, 8(3), 2062015.

Kasiyun, S. (2015). Upaya Mengkatkan Minat Baca Sebagai Sarana Untuk Mencerdaskan Bangsa. Jurnal Pena Indonesia, 1(1), 79-95.

Kholifah, W. T., \& Kristin, F. (2021). Pengembangan Bahan Ajar Cerita Bergambar Tematik Untuk Meningkatkan Minat Baca Siswa Sekolah Dasar. Jurnal Basicedu, 5(5), 3061-3072.

Kurniawati, R. T., \& Koeswanti, H. D. (2020). Pengembangan Media Buku Cerita Bergambar Untuk Meningkatkan Kemampuan Membaca Siswa Kelas I Sekolah Dasar. Didaktika Tauhidi: Jurnal Pendidikan Guru Sekolah Dasar, 7(1), 29.

Lestari, M. (2016). Pengembangan Bahan Ajar Ips Berbasis Kontruktivisme . Prespektif Ilmu Pendidikan, 30(2), 99-104.

Lindasari, Y. M., \& Wahyudi. (2021). Pengembangan Bahan Ajar Tematik Untuk Meningkatkan Minat Baca Siswa Kelas V Sekolah Dasar. Jurnal Ilmiah Wahana Pendidikan, 7(2), 278-287.

Lubis, M. A. (2018). Pengembanagan Bahan Ajar Komik Untuk Meningkatkan Minat Baca Siswa Min Ramba Padang Kabupaten Tapanuli Selatan. Jurnal Tarbiyah, 25(2).

Nurjanah, E., \& Hakim, D. (2018). Pengembangan Bahan Ajar Materi Mencerna (Menyimak Cerita Anak) Berbasis Cerita Anak Majalah Bobo. Jurnal Bidang Pendidikan Dasar (Jbpd), 2(1), 69-83.

Nurseto, T. (2012). Membuat Media Pembelajaran Yang Menarik. Jurnal Ekonomi Dan Pendidikan, 8(1), 2021.

Piaget, J., \& Inhelder, B. (2010). Psikologi Anak Terj. Miftahul Jannah. Yogyakarta: Pustaka Pelajar.

Putrisilia, N. A., \& Airlanda, G. S. (2021). Pengembangan E-Book Cerita Bergambar Proses Terjadinya Hujan Untuk Meningkatkan Minat Membaca Siswa Di Sekolah Dasar. Jurnal Basicedu, 5(4), 2036-2044.

Rosyana, A., Ilhamdi, M. L., \& Dewi, N. K. (2021). Pengembangan Buku Cerita Bergambar Berbasis Pendekatan Saintifik Pada Pembelajaran Ipa. Jurnal Pijar Mipa, 16(3), 302.

Sari, I. P., \& Syamsi, K. (2015). Pengembangan Buku Pelajaran Tematik-Integratif Berbasis Nilai Karakter Disiplin Dan Tanggung Jawab Di Sekolah Dasar. Jurnal Prima Edukasi, 3(1), 74. 
590 Pengembangan Media Cerita Bergambar Tentang Penjajahan Belanda untuk Meningkatkan Minat Baca Siswa Sekolah Dasar - Diah Tara Dewi

DOI: https://doi.org/10.31004/basicedu.v6i1.1966

Sari, L. D., \& Wardani, K. W. (2021). Pengembangan Buku Cerita Bergambar Digital Untuk Meningkatkan Karakter Tanggung Jawab Siswa Di Sekolah Dasar. Jurnal Basicedu, 5(4), 1968-1977.

Sugiyono. (2015). Metode Penelitian Kuantitatif, Kualitatif, Dan R\&D. Bandung: Alfabeta.

Sukmadinata. (2016). Metode Penelitian Pendidikan. Bandung: Rosdakarya.

Suryaningsih, E., \& Fatmawati, L. (2017). Pengembangan Buku Cerita Bergambar Tentang Mitigasi Bencana Erupsi Gunung Api Untuk Siswa Sd. Profesi Pendidikan Dasar, 4(2), 112-124.

Tarigan, N. T. (2018). Pengembangan Buku Cerita Bergambar Untuk Meningkatkan Minat Baca Siswa Kelas Iv Sekolah Dasar. Jurnal Curere, 2(2), 141-152.

Vindaswari, R. F., \& Ulfah, A. (2018). Pengembangan Buku Crita Bergambar Anak Berbasis Nilai- Nilai Kepedulian Bagi Peserta Didik Kelas 2 Sekolah Dasar. Jurnal Fandadikdas (Fundamental Pendidikan Dasar), 1(3), 148-160. 